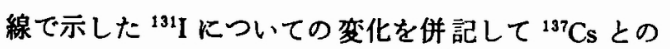
関係をわかり易くした。

困で実線と破線との間，すなわちQ $Q_{e 1}$ の変化とその 大きさを見ると（12)式で示したよ5に時間とともに 当初の gap 内蔵量 $G_{4}$ が出て来る状況を示している。そ してT以降 $Q_{e 2}$ として残りが出て来る。前に述べたよ らにQ $Q_{e 1}$ にいて横軸の $T$ は欠陷発生からの経過時間 と見てょい。なお $Q_{\mathrm{e} 2}$ の量のうちの $C_{4}$ 相当分，すなわ ちペレットからの逸出量は極めて爰慢でほとんどわか らないであろう。したがって，Qe1 がほとんど一定に なった後は実質的にもら出てこないと見てよい。観測 上も紛らわされることはない。

ここで $\sigma$ が認められる場合は $\sigma G_{4}$ に止まるであろ

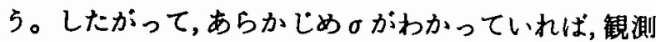
して得た全放出量を修正して $G_{4}$ を求めることができ る。そらすれば $\sigma=1$ として計算された理論曲線Fig. 6 から $t_{0}$ を察することができる。あらかじめ $\sigma$ がわかっ ていれば，Fig. 3,4,6からも運転中直ちに神が察せら れる。しかしこれにはまず $t_{0}$ のわかった然料について

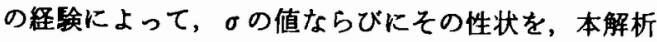
を利用してあらかじめ調べておく必要がある。

\section{I. 結言}

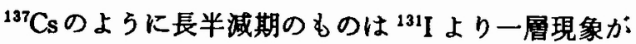
単純である。つまり然料の然焼時間に応じて gapにた まった量が久陷発生とともに出てくるが，この出方は その後の出力変動にほとんど関係しない。これによっ て久宿の発生した燃料のその時までの然焼時間を判定 しょらとしたものである。

この際ベレットから出る分は甚しく緩慢で，それだ け量的にす少ない。これを逆に見れば久陌発生後, 数 $10 \mathrm{~h}$ で現象は終って後は任とんと識別解积の外にきて しまう。すなわちぺレットからの逸出分は理論上は長 く続くが，極めて少量である。前述のような特別な現 象, 例えば gap に水か浸入するとかして gap 内に固着 している成分 $(1-\sigma) G_{4}$ に異常が発生するとか, ペレッ トに異常現象か起きるとかすれば，量的に増してくる ことがあるかる知れない。

Csの化学的性質に爁みても，欠陷検出は常に ${ }^{131} I,{ }^{133} \mathrm{I}$,
${ }^{135}$ I で行い，次陷発生を発見したら直ちに同一試料に ついて ${ }^{131} \mathrm{I},{ }^{137} \mathrm{Cs}$ の値を追跡すると,上の解析は有意義 に利用できる。 $t_{0}$ を正しく求めるには， ${ }^{137} \mathrm{Cs}$ の固着率 $(1-\sigma)$ を求めておく必要がある。妒内の全部が新㷦料 であるよらな場合，欠陥が出れば好機逸すべからずて ある。しかしこの $\sigma$ の値は原子炬の運転時間, 燃料 の種類, 久陷のあり方等に影響されるかる知れない。 こののの大きさとかその変動は然料, 特に被覆内面等 のあり方を判断するのに便宜を与えるであろう。

以上，本報までの解析結果を示す図表等は，常に $\beta_{i}$ を著者の値で一定に仮定しているから，䇴密には各炉 ごとに修正する必要がある。また，炉内出力分布は従来 とも一定として扱ってきたが，分布を考えるならば $a / N_{0}=F P / N_{0}$ の $P / N_{0} を \mathrm{kWt} / \mathrm{cm}$ で考えればよい。 観測記録を縦横に駆使すれば，炬心の現象をそれだけ 詳しく把握できるであろう。

日本原子力研究所安全工学部 石渡名澄氏, 保健物理 部沼宮内眤雄氏ならびに関俰の方々に長期にわたっ て格別のご援助を頂いたことを厚くお礼申し上げる次 第である。

本報を以って久陷検出に関する報告を終了する。当 初より日本原子力研究所, 三菱原子然料㑣, 原子燃料工 業俳ならびに関保の方々のご援助とご鞭撻に対し㳭甚 の謝意を表します。

\section{一考女瀻—}

（1）青木敏男: 原子力誌，19[2]，102 106 (1977).

(2) 同上: 同上, 22[4], 241 246 (1980).

(3) 同 上: 同上, 24[12], 944 948 (1982).

(4) 同上: 同上, 25[1]，29 34 (1983).

(5) 同上: 同上, 25[2], 102 107 (1983).

(6) 同上: 同上, 25[12], 986 992 (1983).

(7) 同上: 同上, 26[6], 489 495 (1984).

(8) 同上: 同上, 26[9], 768 773 (1984).

(9) Regulatory Guide, NUREG-0017, (Apr. 1976).

(10) 㷊料安全特別専門委員会: ジルカ口イ被覆管の㐫力腐蝐 割れに関する調查, NEN-ANSEN, No. 2, (1978).

(11) 吾勝水子：原子炉内の放射性核㮔, JAERI-M, 82 169 (1982).

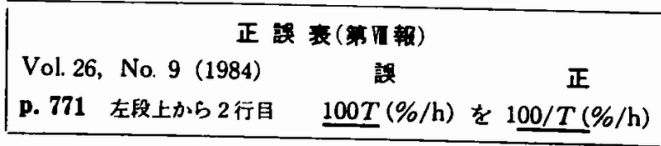

